\title{
Production structure of the services sector in countries at different development levels
}

\author{
Kênia Barreiro de Souza, Suzana Quinet de Andrade Bastos \\ and Fernando Salgueiro Perobelli
}

ABSTRACT

Although the services sector accounts for nearly $70 \%$ of employment and income in developed and developing countries alike, it is well known that the economic performance of the tertiary sector does not depend exclusively on its capacity to add value. This article will evaluate the productive structure of the sector, by considering intra- and inter-sectoral relations in three countries with different development levels: Brazil, the United Kingdom and the United States. The article uses data from the 1995, 2000 and 2005 OECD input-output tables, to calculate the field of influence of sectoral links in the purchase and sale of inputs. The results show that the services sector in Brazil is poorly integrated with the rest of the economy; but in the other two countries, the most important links are spread across the economy as a whole.

KEYWORDS

JEL CLASSIFICATION

AUTHORS
Tertiary sector, trade in services, productivity, developed countries, developing countries, statistics, case studies, Brazil, United States, United Kingdom, Ireland

C67, L8, R11

Kênia Barreiro de Souza, Regional Development and Planning Centre (cedeplar) - Federal University of Minas Gerais (ufmg), Faculty of Economics Sciences, Federal University of Minas Gerais. keniabs@ cedeplar.ufmg.br

Suzana Quinet de Andrade Bastos is Professor on the Postgraduate Programme in Applied Economics, in the Faculty of Economics, Federal University of Juiz de Fora. quinet.bastos@ufjf.edu.br

Fernando Salgueiro Perobelli is Professor on the Postgraduate Programme in Applied Economics, in the Faculty of Economics, Federal University of Juiz de Fora, and is a productivity scholarship holder at the National Council for Scientific and Technological Development. fernando.perobelli@ufff.edu.br 


\section{Introduction}

Today, in the early twenty-first century, nearly all industrialized economies have become "service economies" (Maroto-Sánchez, 2010). Although the services sector accounts for nearly $70 \%$ of employment and income in developed and developing countries alike, most of the economics literature focuses on agriculture and manufacturing, while neglecting the role of tertiary activities.

According to data published by the Organization for Economic Cooperation and Development (OECD, 2010a), in 2005 the tertiary sector generated $82.94 \%$ of gross domestic product (GDP) in Luxembourg, and $77.25 \%$ in United States (see table 1).

The economic performance of the tertiary sector does not depend exclusively on its capacity to add value relative to the other sectors. Other indicators, such as the balance of trade in services, reveal sharp differences between developed economies and Brazil (see table 2). According to Hoekman and Matoo (2008), international trade in services is a good indicator of the maturity of the tertiary sector, since its growth in the more developed countries mainly reflects exports of productive services and services provided to businesses.

Against this backdrop, this article aims to evaluate the productive structure of services through intra- and intersectoral relations in countries of different development levels. For the empirical analysis, three benchmark economies were chosen: Brazil, as the largest economy in Latin America; and the United Kingdom and the United States, as the countries reporting the largest services-trade surpluses in the years 1995, 2000 and 2005.

OECD countries: share of value added by sector, 1995 and 2005

(Percentages)

\begin{tabular}{|c|c|c|c|c|c|c|c|c|c|}
\hline \multirow{2}{*}{ Countries } & \multicolumn{3}{|c|}{ Agriculture } & \multicolumn{3}{|c|}{ Manufacturing } & \multicolumn{3}{|c|}{ Services } \\
\hline & 1995 & 2000 & 2005 & 1995 & 2000 & 2005 & 1995 & 2000 & 2005 \\
\hline Austria & 2.71 & 1.97 & 0.88 & 30.58 & 30.70 & 30.25 & 66.71 & 67.33 & 70.16 \\
\hline Germany & 1.27 & 1.26 & 1.62 & 31.99 & 30.25 & 30.70 & 66.74 & 68.48 & 68.90 \\
\hline Brazil & 8.36 & 7.60 & 5.71 & 33.90 & 35.60 & 35.60 & 57.74 & 56.80 & 65.02 \\
\hline Canada & 2.86 & 2.21 & 1.81 & 30.39 & 32.91 & 32.91 & 66.75 & 64.88 & 65.62 \\
\hline Denmark & 3.47 & 2.61 & 1.43 & 25.08 & 26.81 & 26.81 & 71.45 & 70.58 & 73.06 \\
\hline Slovakia & 5.93 & 4.48 & 3.65 & 38.07 & 35.84 & 35.84 & 56.01 & 59.68 & 59.88 \\
\hline Spain & 4.39 & 4.38 & 3.20 & 29.49 & 29.23 & 29.23 & 66.12 & 66.39 & 67.11 \\
\hline United States & 1.46 & 1.00 & 1.07 & 28.20 & 23.32 & 23.32 & 70.34 & 75.68 & 77.25 \\
\hline Finland & 4.53 & 3.78 & 2.77 & 32.59 & 33.38 & 33.38 & 62.89 & 62.84 & 64.75 \\
\hline France & 3.23 & 2.71 & 2.29 & 26.19 & 24.68 & 24.68 & 70.58 & 72.61 & 74.83 \\
\hline Indonesia & 16.85 & 16.08 & 13.06 & 38.98 & 45.82 & 45.82 & 44.17 & 38.10 & 40.14 \\
\hline Italy & 3.31 & 2.80 & 2.20 & 30.28 & 28.43 & 28.43 & 66.42 & 68.78 & 70.93 \\
\hline Japan & 1.76 & 1.81 & 1.38 & 32.65 & 25.79 & 25.79 & 65.59 & 72.39 & 70.56 \\
\hline Luxembourg & 1.03 & 0.68 & 0.43 & 21.74 & 18.35 & 18.35 & 77.23 & 80.96 & 82.94 \\
\hline Norway & 3.02 & 2.13 & 1.53 & 34.03 & 41.71 & 41.71 & 62.95 & 56.16 & 55.60 \\
\hline Netherlands & 3.52 & 2.76 & 2.09 & 27.76 & 25.80 & 25.80 & 68.72 & 71.44 & 73.74 \\
\hline Poland & 7.46 & 3.52 & 4.53 & 39.86 & 33.83 & 33.83 & 52.68 & 62.65 & 64.76 \\
\hline Portugal & 5.12 & 3.78 & 2.84 & 29.77 & 27.58 & 27.58 & 65.11 & 68.65 & 72.63 \\
\hline United Kingdom & 1.77 & 1.02 & 0.67 & 30.84 & 27.34 & 27.34 & 67.39 & 71.64 & 75.85 \\
\hline Sweden & 2.71 & 1.88 & 1.10 & 30.32 & 28.58 & 28.58 & 66.97 & 69.54 & 71.23 \\
\hline
\end{tabular}

Source: prepared by the authors on the basis of Organization for Economic Cooperation and Development (OECD), "Input-output tables" [online] http://www.oecd.org/document/3/0,3343, en_2649_34445_38071427_1_1_1_1,00.html [viewed in April 2010].

a Countries were selected for which data for 1995 and 2005 were published by the OECD. 
TABLE 2

OECD countries: balance of trade in services, 1995, 2000 and 2005

(US\$ billion)

\begin{tabular}{|c|c|c|c|c|c|c|c|c|c|}
\hline \multirow{2}{*}{ Countries a } & \multicolumn{3}{|c|}{1995} & \multicolumn{3}{|c|}{2000} & \multicolumn{3}{|c|}{2005} \\
\hline & Exports & Imports & Balance & Exports & Imports & Balance & Exports & Imports & Balance \\
\hline Austria & 79.90 & 133.40 & -53.50 & 83.20 & 138.20 & -55.00 & 163.50 & 210.20 & -46.70 \\
\hline Germany & 24.30 & 19.30 & 5.00 & 23.10 & 16.50 & 6.60 & 42.40 & 30.60 & 11.80 \\
\hline Brazil & 6.10 & 13.60 & -7.50 & 9.50 & 16.70 & -7.20 & 16.00 & 24.40 & -8.40 \\
\hline Canada & 26.10 & 33.50 & -7.40 & 40.20 & 44.10 & -3.90 & 55.80 & 65.70 & -9.90 \\
\hline Denmark & 13.90 & 13.20 & 0.70 & 24.50 & 22.10 & 2.40 & 43.50 & 37.30 & 6.20 \\
\hline Slovakia & 2.50 & 1.80 & 0.70 & 2.20 & 1.80 & 0.40 & 4.40 & 4.10 & 0.30 \\
\hline Spain & 40.30 & 22.90 & 17.40 & 52.60 & 33.20 & 19.40 & 94.80 & 67.10 & 27.70 \\
\hline United States of America & 219.20 & 141.40 & 77.80 & 298.60 & 223.70 & 74.90 & 389.10 & 313.50 & 75.60 \\
\hline Finland & 7.40 & 9.60 & -2.20 & 7.70 & 9.10 & -1.40 & 17.00 & 17.70 & -0.70 \\
\hline France & 78.90 & 64.50 & 14.40 & 80.60 & 60.80 & 19.80 & 122.30 & 105.70 & 16.60 \\
\hline Indonesia & 5.50 & 13.50 & -8.00 & 5.20 & 15.60 & -10.40 & 12.90 & 22.00 & -9.10 \\
\hline Italy & 57.50 & 51.10 & 6.40 & 56.70 & 55.60 & 1.10 & 89.40 & 90.00 & -0.60 \\
\hline Japan & 65.50 & 122.80 & -57.30 & 69.20 & 116.80 & -47.60 & 106.10 & 134.00 & -27.90 \\
\hline Luxembourg & 10.70 & 7.50 & 3.20 & 20.00 & 13.20 & 6.80 & 40.90 & 24.60 & 16.30 \\
\hline Norway & 13.70 & 13.10 & 0.60 & 17.80 & 15.00 & 2.80 & 29.90 & 29.20 & 0.70 \\
\hline Netherlands & 45.90 & 44.80 & 1.10 & 49.30 & 51.40 & -2.10 & 80.10 & 73.30 & 6.80 \\
\hline Poland & 10.70 & 7.10 & 3.60 & 10.40 & 9.00 & 1.40 & 16.30 & 15.50 & 0.80 \\
\hline Portugal & .. & .. & .. & 9.00 & 7.10 & 1.90 & 15.20 & 10.40 & 4.80 \\
\hline $\begin{array}{l}\text { United Kingdom of Great } \\
\text { Britain and Northern Ireland }\end{array}$ & 84.50 & 66.90 & 17.60 & 124.00 & 101.10 & 22.90 & 216.70 & 169.70 & 47.00 \\
\hline Sweden & 16.40 & 16.80 & 0.40 & 22.70 & 24.60 & -1.90 & 43.10 & 35.30 & 7.80 \\
\hline
\end{tabular}

Source: prepared by the authors on the basis of Organization for Economic Cooperation and Development (OECD), "Input-output tables" [online] http://www.oecd.org/document/3/0,3343,en_2649_34445_38071427_1_1_1_1,00.html [viewed in April 2010].

a Countries were selected for which data were available for the entire period.

Productive structures were compared using data from the OECD's 1995, 2000 and 2005 input-output tables (OECD, $2010 \mathrm{~b}$ ) in the light of the growth of the services sector.

This article is divided into five sections, including the introduction. While section II reviews the literature on the services sector and the "tertiarization" process, section III provides details of the methodology employed and describes the data used in the empirical analysis. The fourth section offers a formal analysis of the results obtained, and section V sets out the main conclusions.

\section{II}

The services sector and tertiarization 1

Despite attempts to characterize services, the growing technological dynamic of the productive process makes it hard to distinguish between economic sectors (Arriagada,

1 The term "tertiarization" refers to the tertiary-sector expansion process.
2007). According to this author, there is no consensus over the classification of service activities, which remains a complex issue requiring a multidisciplinary approach:

The rapid pace of change in the introduction of new technologies, which generate products with different characteristics but fulfil functions similar to those of traditional modes of production, distribution and 
consumption, introduce additional complexities that have rendered classification systems obsolete (Arriagada, 2007, p. 31).

Intra- and inter-sectoral boundaries are becoming more tenuous (Bernardes, Bessa and Kalup, 2005); and the distinction between manufacturing activities and those of the services sector is becoming less clear-cut (Pilat and Wölfl, 2005; Wölfl, 2005; Arriagada, 2007; Lima and Rocha, 2009; Siddiqui and Saleem, 2010). An inter-sectoral convergence process is unfolding, such that the manufacturing sector is increasingly serviceoriented, and the services sector is gradually becoming more industrialized (Gallouj, 2002). As Boden and Miles (2000), cited in Freire (2006a, p. 35) note, the economic system can be viewed as a network of interconnected functions; for historical reasons some of these are classified as services and others as manufacturing.

Although it is hard to characterize the heterogeneous group of activities encompassed by the tertiary sector, the debate over the economic role of services has not yet been fully integrated into core economic theory, and the term "tertiary" continues to be used to refer to all activities not belonging to the agriculture or manufacturing sectors (Delgado, 2005).

Based on that definition, the trend of tertiary-sector expansion is known as tertiarization and is explained by various factors, including: (i) an increase in final demand by households, stemming from the high income-elasticity of demand for services and rising incomes; (ii) growth of the intermediate consumption of services, as production processes become more flexible; and (iii) productivity differences between sectors, which raise the production costs of tertiary activities.

To understand the tertiarization process, the composition and degree of heterogeneity of tertiary activities need to be established, because the multiple trends affecting this process manifest themselves in different ways at different economic development levels. Each country's degree of maturity and socioeconomic development is reflected in its productive structure and, hence, in the composition and dynamism of the tertiary sector.

Those characteristics reflect the set of historical and socioeconomic factors that have permeated the expansion of the tertiary sector, combining the effects of variations in final and intermediate demand and activity differences between sectors in various ways. Wölfl (2005) argues that countries are distinguished by the role and performance of the services sector; and the differences can explain how pro-services structural change affects economic growth.

\section{The historical and socioeconomic determinants of tertiarization}

As noted above, Wölfl (2005) argues that each country differs in terms of the role and economic performance of its services sector. While the growth of the modern branch of services may reflect the trend of the production structure and society itself, which requires more flexible production and a wider range of services, other branches of the tertiary sector can be characterized by low-productivity and low-skilled labour, owing to supply-side pressures in the labour market (Weller, 2004).

Thus, the effects on growth differ considerably between one activity and another, because they depend on structural and market characteristics (Pilat, 2005). This author finds that a well-functioning services sector is crucial for understanding not only the economic performance of individual countries, but also the welfare of their citizens. A diverse and productive services sector can enhance the performance of other economic sectors (particularly manufacturing), raising quality and boosting competitiveness throughout the economy.

Various explanations can be found for tertiarization. Bell (1973) describes the expansion of the tertiary sector in developed countries since the advent of the post-industrial society, marked by income growth that fuels greater consumption of services such as health, entertainment, education and culture. In that society, technological development would be expected to reduce the proportion of manual and unskilled workers, and most of the population would be engaged in producing intangible goods.

Knowledge would be the key factor for economic growth, while education and vocational training would be targeted on increasing welfare and social advancement. The tertiary sector would contribute to that process in two ways: producing social development and welfare, and playing a strategic role by enhancing the competitiveness of enterprises and the economy as a whole (Weller, 2004).

At the same time, since the 1950s developed countries have been undergoing a process of demographic growth and migration of the rural population to urban areas (Paiva, 1986). According to Pandit and Casetti (1989), those developments increased the labour supply beyond the ability of those countries' industries to fully absorb it, leading to excessive growth of the services sector, with low-productivity jobs in traditional or even informal tertiary activities.

Nonetheless, not all tertiarization processes are entirely spurious (or associated with low-quality jobs) in developing countries, or entirely genuine (or linked 
to skilled functions with great capacity to add value) in industrialized economies (Weller, 2004). There are multiple trends involved in tertiarization, and all economies display spurious and genuine processes simultaneously, in proportions that vary according to their development level (Weller, 2004).

The historical background that characterizes the "multiple trends" of tertiarization in industrialized and developing countries as described by Weller (2004) is reviewed below.

\section{Tertiarization in developed economies}

Until the early 1970s, the predominant accumulation pattern in developed capitalist economies was Fordism, ${ }^{2}$ characterized by mass production, economies of scale, technical and internal division of labour and vertical integration (Coffey and Bailly, 1991). In the mid-1960s, as war-ravaged economies recovered and the importsubstitution movement gained ground in "third world" countries (particularly in Latin America), international competition intensified. Against this backdrop, firms saw signs of faltering revenues, until the first oil crisis in 1973 pushed up production costs and caused the collapse of the Fordist model.

The 1970s and 1980s were a turbulent period of economic reconstruction and social and political readjustment (Harvey, 1992, p. 140). In economic terms, a new pattern of accumulation emerged, known as "flexible production", which was characterized by a process of enterprise horizontalization, prioritizing core competencies; and co-operation became a strategic tool for maintaining competitiveness (Vargas and Zawislak, 2006). According to Coffey and Bailly (1991), activities in the flexible production system had to be outsourced to keep pace with technical changes.

The growth of advanced services is directly related to the emergence of the new information and communications technologies (ICT) paradigm, which allows for greater integration between economic sectors and, consequently, greater information and knowledge exchange between manufacturing and services, promoting the innovation process (Castellacci, 2008). The technological revolution thus gave rise to the "knowledge-based economy" (Jesus, 2005), the characteristics of which include a strengthening of knowledge-intensive services provided to firms (Muller

2 The term "Fordism" refers to the production-line model implemented by Henry Ford, the United States automobile manufacturer. and Zenker, 2001), which act as "innovation promotion agents" (Bernardes, Bessa and Kalup, 2005).

According to Castells (1999), advanced services, such as finance, insurance, real estate, consulting, legal advisory services, advertising, projects, marketing, public relations, security, data compilation and information systems management, as well as research and development (R\&D) and innovation, are responsible for knowledge production and the flow of information. Barras (1986) contends that the ICT revolution actually represents an "industrial revolution" for the services sector.

Consequently, in cities at the end of the twentieth century, the flow of intangible goods outweighed the flow of tangible goods (Phelps and Ozama, 2003). As a result, cities which in the Fordism period constituted material production hubs became centres of production for communication, ideas, knowledge and information (Storper and Venables, 2004). Cities are the crucial locations for the advanced services and telecommunications needed to implement and manage global economic operations (Sassen, 1999, p. 35). As this author emphasizes, burgeoning demand for services that are increasingly complex, diversified and specialized, makes them economically viable and allows the corresponding activities to expand mainly in the large urban centres.

According to Bailly, Maillat and Coffey (1987), small urban centres accommodate service activities with potential to contribute to local economic growth, by directly influencing production and supplying specialized services, not only locally but also to neighboring regions and the large centres nearby. These authors argue that the existence of strategic services such as maintenance, transport, accounting and legal services, is necessary both for existing firms and for the creation of new enterprises, and also for the relocation of those with little capacity to internalize services (particularly small and medium-sized firms).

The flexibility requirements of the post-Fordist, post-industrial, or knowledge economy, fuelled the spread of specialized services used mainly as intermediate productive inputs. This was very different from what occurred in the early 1950s, when final demand growth and the low productivity of services compared to the other sectors could fully explain tertiarization.

In this context, the expansion of the tertiary sector in industrialized countries can generally be seen as a sign of the evolution of the production structure - through the growth of intermediate demand - and of society itself, through the consumption of specialized services (Weller, 2004). Thus, when the expansion of services 
is linked to a genuine tertiarization process (in other words growth in services linked to production and social welfare and advancement) it represents an expression of the post-industrial society (Bonet, 2007).

\section{Tertiarization in developing economies}

The expansion of the tertiary sector in developing economies is based on concomitant processes of worker inclusion and exclusion (Weller, 2004). First, activities linked to systemic productivity and social production grows, thereby generating high-productivity and highquality jobs. Nonetheless, a portion of the jobs created reflect labour-supply pressures and use labour of low quality and low productive capacity. Thus:

When talking of tertiarization in Latin America and the Caribbean, it is always important to remember the simultaneous presence of spurious and genuine processes, and thus avoid inappropriate simplifications such as identifying tertiarization with informality or interpreting it exclusively as an expression of post-industrial modernization (Weller, 2004, p. 174).

Unlike what happened in the industrialized countries, where technical progress increased efficiency and productivity, thereby raising wages and fuelling an expansion of demand for both goods and services, in late-industrializing countries technical progress affected only a few sectors, particularly those linked to food and raw materials produced at low cost and serving the large industrial centres (Pinto, 1984).

This happened because when the developing countries, particularly Latin American ones, embarked on their industrialization process, most European countries, along with the United States and Japan, had already achieved a higher technological level that was capital-intensive and required less labour each period. These characteristics were transferred to the nascent Latin American manufacturing through large transnational firms and imported means of production (machinery and raw materials), causing structural unemployment (López and Cobos, 2008). As the resultant labour surplus was not needed for agricultural production, according to Roggero (1976) and Kaztman (1984), the dynamic shortfall fuelled disproportionate growth in services. ${ }^{3}$
Manufacturing expansion could not absorb all workers leaving the countryside for the cities, causing severe imbalances in the labour market and excessive expansion of the tertiary sector, as a reflection of hidden unemployment (Roggero, 1976; Carneiro, 1994; Mazumdar, 2010; Mitra, 2010).

In the secondary sector, particularly in the least developed countries, investment constraints reduced the capacity to absorb labour and increase production capacity. This reflects the small size of domestic and external markets for the consumption of manufactured goods, compounded by rigid technical coefficients of production and scant domestic saving (Kon, 2004 and 2007).

Spurious tertiarization, involving few entry barriers and providing a refuge for low-productivity, low-skilled and low-paid labour, produces an expansion of services in response to supply pressures on the labour market (Carneiro, 1994; Melo and others, 1998; Amadeo and Pero, 2000; Bonet, 2007; Mitra, 2010).

For Kaztman (1984), this was merely the first wave of tertiarization in Latin America, and also the primary effect of the rural-urban migration of agricultural labour. Although workers originating in the agriculture sector are low-skilled, they boost demand for goods and services, thereby increasing integration between the secondary and tertiary sectors and creating new branches of services of a different type, closely linked to the inputs needed for industrial development.

In the 1990s, trade liberalization promoted changes in the production structure and gave renewed momentum to the tertiarization process. In the case of Brazil, the manufacturing sector was directly affected by the policies adopted, which exposed domestic manufacturing to international competition and forced industries to raise productivity and reduce employment. The result was an increasingly excessive growth of the tertiary sector, which absorbed the excess labour (Hilgemberg, Campos and Hilgemberg, 2009).

Having reviewed the differences in the formation of the tertiary sector, the next step is to identify the effects of the different contexts on the behaviour of services in developed and developing countries.

of the economically active population and unemployment caused by technical progress (Roggero, 1976; Kaztman, 1984; Escaith, 2006).
3 The concept of dynamic shortfall was formulated by Prebisch in the early 1970 s and can be understood as the inability of the productive system to generate sufficient jobs to absorb the growth 


\section{III}

\section{Methodology}

The emphasis on inter-sectoral relations and the concern for the growth dynamic of service activities have meant that input-output tables have often been used in the analysis of the sector. According to Schettkat and Yocarini (2003), this is an appropriate methodology for studying the gross output of services, since it allows inter-sectoral production relations to be analysed with some degree of intra-sectoral breakdown.

The input-output model consists of a system of linear equations that describe how the output of a given sector is distributed through the rest of the economy. The basic information used in the model thus corresponds to inter-sectoral product flows, and also requires data on production destined for final consumption and that used as other productive inputs, such as labour, capital and imports, among others (Miller and Blair, 2009).

In the case of an economy with three sectors (primary, secondary and tertiary, for example), the input-output table data would be organized as shown in table 3 .

\begin{tabular}{|c|c|c|c|c|c|c|c|}
\hline & & & \multicolumn{5}{|c|}{ Destination of production } \\
\hline & & & \multicolumn{3}{|c|}{ Sectors } & \multirow{2}{*}{$\begin{array}{l}\text { Final demand } \\
(\mathrm{C}+\mathrm{I}+\mathrm{G}+\mathrm{X})\end{array}$} & \multirow{2}{*}{$\begin{array}{l}\text { Gross production } \\
\text { value }\end{array}$} \\
\hline & & & Primary & Secondary & Tertiary & & \\
\hline \multirow{6}{*}{$\begin{array}{l}\text { Composition of } \\
\text { output from the } \\
\text { purchase standpoint }\end{array}$} & \multirow{3}{*}{ Sectors } & Primary & $z_{11}$ & $z_{12}$ & $z_{13}$ & $f_{l}$ & $x_{1}$ \\
\hline & & Secondary & $z_{21}$ & $z_{22}$ & $z_{23}$ & $f_{2}$ & $x_{2}$ \\
\hline & & Tertiary & $z_{31}$ & $z_{32}$ & $z_{33}$ & $f_{3}$ & $x_{3}$ \\
\hline & \multirow{3}{*}{\multicolumn{2}{|c|}{$\begin{array}{l}\text { Gross value added } \\
\text { Other payments } \\
\text { Gross production value }\end{array}$}} & $v_{1}$ & $v_{2}$ & $v_{3}$ & & \\
\hline & & & $p_{1}$ & $p_{2}$ & $p_{3}$ & & \\
\hline & & & $x_{1}$ & $x_{2}$ & $x_{3}$ & & \\
\hline
\end{tabular}

Source: prepared by the authors on the basis of R.E. Miller and P.D. Blair, Input-Output Analysis: Foundations and Extensions, New York, Cambridge University Press, 2009.

The total output of the primary sector can be defined as the sum of sector production flows for use as intermediate inputs $\left(z_{11}, z_{12}, z_{13}\right)$ and flows to meet final demand $\left(f_{1}\right)$, consisting of consumption by households $(\mathrm{C})$, investment (I), government expenditure $(\mathrm{G})$ and exports $(\mathrm{X})$ :

$$
x_{1}=z_{11}+z_{12}+z_{13}+f_{1}
$$

In addition, from the standpoint of purchases by the primary sector, its production corresponds to the intermediate flows of input purchases $\left(z_{11}, z_{21}, z_{31}\right)$, plus the value added by the sector $\left(v_{1}\right)$ and other payments $\left(p_{1}\right)$. In general terms, the sum of the lines of the matrix represents each sector's total sales, and the sum of the columns represents its total purchases.
Thus, considering all sectors of the economy from the sales perspective, the economy's total output can be represented by the following system of equations: ${ }^{4}$

$$
\begin{aligned}
& x_{1}=z_{11}+z_{12}+z_{13}+f_{1} \\
& x_{2}=z_{21}+z_{22}+z_{23}+f_{2} \\
& x_{3}=z_{31}+z_{32}+z_{33}+f_{3}
\end{aligned}
$$

The ratio between each sector's input use and its total production comprises the technical coefficients $\left(a_{i j}\right)$, or input-output coefficients of the Leontief production function used in input-output models. The basic premise

4 If there were $n$ service sectors, for example, the element $x_{3}$ would be an $n \times 1$ vector, the element $z_{33}$ would be a $n \times n$ matrix, and so on. 
of this production function is that inter-industry flows from sector $i$ to sector $j$ depend only on the gross output of sector $j$ in the period in question. Consequently, the ratio between the inputs purchased from sector $i$ to be used in the production of $j$ is given by:

$$
a_{i j}=\frac{z_{i j}}{x_{j}}
$$

Rewriting equation (3), intermediate consumption between sectors $i$ and $j$ can be defined as $z_{i j}=a_{i j} x_{j}$. Thus, substituting this relation into (2) gives:

$$
\begin{aligned}
& x_{1}-a_{11} x_{1}-a_{12} x_{1}-a_{13} x_{1}=f \\
& x_{2}-a_{21} x_{2}-a_{22} x_{2}-a_{23} x_{2}=f_{2} \\
& x_{3}-a_{31} x_{3}-a_{32} x_{1}-a_{33} x_{3}=f_{3}
\end{aligned}
$$

Simplifying (4):

$$
\begin{aligned}
\left(1-a_{11}\right) x_{1}-a_{12} x_{1}-a_{13} x_{1} & =f_{1} \\
-a_{21} x_{2}-\left(1-a_{22}\right) x_{2}-a_{23} x_{2} & =f_{2} \\
-a_{31} x_{3}-a_{32} x_{1}-\left(1-a_{33}\right) x_{3} & =f_{3}
\end{aligned}
$$

The system (5) can be represented in matrix form as:

$$
(I-A) x=f
$$

where:

$$
I\left|\begin{array}{lll}
1 & 0 & 0 \\
0 & 1 & 0 \\
0 & 0 & 1
\end{array}\right|=; A=\left|\begin{array}{lll}
a_{11} & a_{12} & a_{13} \\
a_{21} & a_{22} & a_{23} \\
a_{31} & a_{32} & a_{33}
\end{array}\right| ; x=\left|\begin{array}{l}
x_{1} \\
x_{2} \\
x_{3}
\end{array}\right| ; f=\left|\begin{array}{l}
f_{1} \\
f_{2} \\
f_{3}
\end{array}\right|
$$

Solving (6) for $x$ gives:

$$
x=(I-A)^{-1} f=B f
$$

where:

$$
B=\left|\begin{array}{lll}
b_{11} & b_{12} & b_{13} \\
b_{21} & b_{22} & b_{23} \\
b_{31} & b_{32} & b_{33}
\end{array}\right|
$$

$B$ is known as the Leontief inverse matrix, or total requirements matrix.

\section{Field of influence}

A field-of-influence analysis was performed to evaluate the importance of each of the links between economic sectors, thereby making it possible to identify the most important inter-sectoral relations. A coefficient is considered relevant if its variations have pronounced effects on the final results of the economy as a whole (Guilhoto and others, 1994).

To formulate the methodology of the field-ofinfluence analysis, Sonis and Hewings (1989) — cited in Miller and Blair (2009) — used the ratio between variations in the direct production coefficients (matrix $A$ ) and variations in the total requirements matrix (matrix $B$, which is equivalent to $\left.(I-A)^{-1}\right)$.

Thus, in the case of a variation of $\Delta A$ in the coefficients of matrix $A$, which generates a new technical coefficients matrix $A^{*}=A+\Delta A$, the total requirements matrix can be rewritten as: $B^{*}=(I-A-\Delta A)^{-1}$.

To evaluate the effects of variations in each of the elements of matrix $A$, there needs to be a small variation $\varepsilon$ in each $a_{i j}$ individually, in other words, $\Delta A$ is a matrix $E=\left|\varepsilon_{i j}\right|$, such that:

$$
\varepsilon_{i j}=\left\{\begin{array}{l}
\varepsilon \text { se } i=i_{1} \text { ej }=j_{1} \\
0 \text { se } i \neq i_{1} \text { ej } \neq j_{1}
\end{array}\right.
$$

The field of influence of each coefficient is approximately equal to:

$$
F\left(\varepsilon_{i j}\right)=\frac{B^{*}-B}{\varepsilon_{i j}}
$$

Thus the total influence of each technical coefficient, or each link in the input-output table, is given by:

$$
s_{i j}=\sum_{k=1}^{n} \sum_{l=1}^{n}\left[f_{k l}\left(\varepsilon_{i j}\right)^{2}\right]
$$

Consequently, the larger is $s_{i j}$, the greater will be the field of influence of coefficient $a_{i j}$.

\section{Description of the data}

The OECD matrices for Brazil, the United States and the United Kingdom for 1995, 2000 and 2005, include 48 sectors, 18 of which relate to services. Nonetheless, not all of those sectors have data available for the first two countries, so the matrices had to be reconciled, resulting in a total of 26 sectors, 10 of which correspond 
to services (see annex 1). The OECD data are expressed in the currency of each country, in other words in reais, dollars and pounds, at current basic prices.

The data of the input-output tables are presented using the basic structure shown in table 3 . From the sales standpoint (see table 4), sector production is represented by the rows of the matrix. These outputs are destined for the rest of the domestic market (columns corresponding to intermediate consumption and domestic consumption) and to the external market (column corresponding to exports).

Brazil, United States, United Kingdom: distribution of gross production value from the sales perspective, 1995-2005

(Percentages)

\begin{tabular}{|c|c|c|c|c|c|c|c|c|c|}
\hline \multirow[b]{2}{*}{ Origin: } & \multirow{2}{*}{\multicolumn{2}{|c|}{ Destination: }} & \multicolumn{4}{|c|}{ Intermediate consumption } & \multirow{2}{*}{$\begin{array}{c}\text { Domestic } \\
\text { consumption }\end{array}$} & \multirow{2}{*}{ Exports } & \multirow{2}{*}{$\begin{array}{c}\text { Gross } \\
\text { production } \\
\text { value }\end{array}$} \\
\hline & & & Agriculture & Manufacturing & Services & Total & & & \\
\hline \multirow{9}{*}{ Agriculture } & BRA & 1995 & 14.64 & 45.26 & 3.88 & 63.77 & 34.59 & 1.64 & 100.00 \\
\hline & & 2000 & 14.91 & 43.94 & 3.55 & 62.39 & 33.99 & 3.62 & 100.00 \\
\hline & & 2005 & 14.91 & 43.95 & 3.54 & 62.39 & 33.99 & 3.62 & 100.00 \\
\hline & USA & 1995 & 23.86 & 46.99 & 12.15 & 83.00 & 7.21 & 9.79 & 100.00 \\
\hline & & 2000 & 19.87 & 50.63 & 7.56 & 78.06 & 13.78 & 8.16 & 100.00 \\
\hline & & 2005 & 19.82 & 50.63 & 6.44 & 76.89 & 15.01 & 8.10 & 100.00 \\
\hline & GBR & 1995 & 10.09 & 46.06 & 8.55 & 64.70 & 28.28 & 7.02 & 100.00 \\
\hline & & 2000 & 7.20 & 34.45 & 8.42 & 50.07 & 43.19 & 6.74 & 100.00 \\
\hline & & 2005 & 6.21 & 31.43 & 8.00 & 45.65 & 46.06 & 8.29 & 100.00 \\
\hline \multirow{9}{*}{ Manufacturing } & BRA & 1995 & 2.74 & 38.35 & 16.10 & 57.18 & 33.98 & 8.83 & 100.00 \\
\hline & & 2000 & 2.95 & 38.08 & 18.91 & 59.95 & 30.30 & 9.75 & 100.00 \\
\hline & & 2005 & 2.48 & 36.84 & 12.48 & 51.80 & 40.01 & 8.19 & 100.00 \\
\hline & USA & 1995 & 1.06 & 33.70 & 22.82 & 57.58 & 31.56 & 10.86 & 100.00 \\
\hline & & 2000 & 0.92 & 28.78 & 21.70 & 51.41 & 36.44 & 12.15 & 100.00 \\
\hline & & 2005 & 0.75 & 26.61 & 18.16 & 45.52 & 44.91 & 9.57 & 100.00 \\
\hline & GBR & 1995 & 1.11 & 28.59 & 15.72 & 45.42 & 24.49 & 30.09 & 100.00 \\
\hline & & 2000 & 0.57 & 24.84 & 17.00 & 42.41 & 28.04 & 29.55 & 100.00 \\
\hline & & 2005 & 0.51 & 28.17 & 12.67 & 41.34 & 37.11 & 21.55 & 100.00 \\
\hline \multirow{9}{*}{ Services } & BRA & 1995 & 1.43 & 8.64 & 19.05 & 29.12 & 69.39 & 1.50 & 100.00 \\
\hline & & 2000 & 1.38 & 9.18 & 17.65 & 28.21 & 69.34 & 2.45 & 100.00 \\
\hline & & 2005 & 1.62 & 12.27 & 17.64 & 31.52 & 65.61 & 2.86 & 100.00 \\
\hline & USA & 1995 & 0.52 & 7.98 & 26.14 & 34.64 & 62.99 & 2.37 & 100.00 \\
\hline & & 2000 & 0.36 & 7.96 & 28.88 & 37.20 & 60.44 & 2.36 & 100.00 \\
\hline & & 2005 & 0.32 & 9.36 & 28.90 & 38.59 & 58.79 & 2.62 & 100.00 \\
\hline & GBR & 1995 & 0.55 & 8.30 & 30.72 & 39.57 & 54.75 & 5.68 & 100.00 \\
\hline & & 2000 & 0.41 & 7.69 & 35.01 & 43.10 & 49.69 & 7.21 & 100.00 \\
\hline & & 2005 & 0.31 & 7.75 & 30.57 & 38.63 & 52.26 & 9.11 & 100.00 \\
\hline \multirow{9}{*}{ Total } & BRA & 1995 & 2.92 & 22.91 & 16.77 & 42.61 & 53.04 & 4.36 & 100.00 \\
\hline & & 2000 & 2.98 & 23.42 & 17.16 & 43.56 & 50.93 & 5.51 & 100.00 \\
\hline & & 2005 & 2.98 & 26.46 & 14.13 & 43.56 & 50.93 & 5.51 & 100.00 \\
\hline & USA & 1995 & 1.15 & 16.73 & 24.83 & 42.72 & 52.13 & 5.15 & 100.00 \\
\hline & & 2000 & 0.78 & 14.20 & 26.64 & 41.62 & 53.29 & 5.09 & 100.00 \\
\hline & & 2005 & 0.72 & 15.11 & 25.37 & 41.20 & 54.02 & 4.78 & 100.00 \\
\hline & GBR & 1995 & 0.92 & 15.81 & 25.28 & 42.00 & 44.12 & 13.87 & 100.00 \\
\hline & & 2000 & 0.53 & 12.77 & 29.68 & 42.99 & 43.58 & 13.43 & 100.00 \\
\hline & & 2005 & 0.43 & 14.34 & 24.77 & 39.54 & 47.47 & 12.99 & 100.00 \\
\hline
\end{tabular}

Source: prepared by the authors on the basis of Organization for Economic Cooperation and Development (OECD), "Statistics" [online] http:// stats.oecd.org/Index.aspx?DataSetCode=CSP2010 [viewed in April 2010]. 
In output-destination terms, while services production is concentrated on domestic consumption in all three countries, the highest percentage is in Brazil. The proportion of services produced for intermediate consumption in the Brazilian economy was just $29.12 \%$ in $1995,28.21 \%$ in 2000 and $31.52 \%$ in 2005 - compared to $34.64 \%, 37.20 \%$ and $38.59 \%$ in the United States, and $39.57 \%, 43.10 \%$ and $38.63 \%$ in the United Kingdom, respectively, in those years.

Gross production value (GPV) measured in terms of purchases consists of the inputs used in each sector's production, plus taxes, profit margins and transport, imported inputs and gross value added. Thus, the sectors identified in the columns are the suppliers of inputs used in the production of the sectors indicated in the rows (see table 5).

The share of intermediate consumption in total services sector GPV is greater in the United States and the United Kingdom than in Brazil. The same is true of the intensity of intra-sectoral relations in the services sector: whereas in Brazil intermediate trade accounted for $19.05 \%$ of services production in $1995,17.65 \%$ in 2000 and $17.64 \%$ in 2005 , the equivalent percentages in the United States were 26.27\%, 29.04\% and 28.90\%, and, in United Kingdom, $30.72 \%, 35.01 \%$ and $30.57 \%$, respectively in the same years.

The proximity ratio between manufacturing and services can also be defined in terms of the use of services as inputs for manufacturing production. Whereas that ratio was $21.39 \%$ in 2005 in the United States, in the case of Brazil it was $11.94 \%$ in 1995 and $11.19 \%$ in 2005 .

The differences in the composition of services in terms of the distribution of GPV in Brazil, compared to the United Kingdom and the United States, reveal the first signs of a less integrated sector (stronger intrasectoral relations and little integration with other sectors) oriented towards domestic final consumption rather than intermediate consumption.

Brazil, United States, United Kingdom: distribution of gross production value from the purchases perspective, 1995-2005 (Percentages)

\begin{tabular}{|c|c|c|c|c|c|c|}
\hline \multicolumn{2}{|l|}{ Destination: } & Origin: & Agriculture & Manufacturing & Services & Total \\
\hline \multirow{9}{*}{ Agriculture } & \multirow{3}{*}{ BRA } & 1995 & 14.64 & 8.72 & 0.54 & 4.77 \\
\hline & & 2000 & 14.91 & 7.65 & 0.48 & 4.42 \\
\hline & & 2005 & 14.91 & 6.41 & 0.57 & 4.42 \\
\hline & \multirow{3}{*}{ USA } & 1995 & 23.87 & 3.01 & 0.36 & 1.65 \\
\hline & & 2000 & 19.88 & 2.63 & 0.15 & 1.10 \\
\hline & & 2005 & 19.82 & 2.32 & 0.13 & 1.06 \\
\hline & \multirow{3}{*}{ GBR } & 1995 & 10.09 & 2.62 & 0.25 & 1.23 \\
\hline & & 2000 & 7.20 & 1.42 & 0.14 & 0.58 \\
\hline & & 2005 & 6.21 & 0.90 & 0.11 & 0.41 \\
\hline \multirow{9}{*}{ Manufacturing } & \multirow{3}{*}{ BRA } & 1995 & 14.21 & 38.35 & 11.64 & 22.21 \\
\hline & & 2000 & 16.97 & 38.08 & 14.77 & 24.42 \\
\hline & & 2005 & 16.98 & 36.84 & 13.68 & 25.17 \\
\hline & \multirow{3}{*}{ USA } & 1995 & 16.57 & 33.88 & 10.63 & 17.96 \\
\hline & & 2000 & 17.90 & 28.93 & 8.26 & 13.99 \\
\hline & & 2005 & 16.30 & 26.61 & 7.95 & 13.67 \\
\hline & \multirow{3}{*}{ GBR } & 1995 & 19.51 & 28.56 & 8.14 & 15.19 \\
\hline & & 2000 & 13.92 & 24.84 & 6.67 & 11.81 \\
\hline & & 2005 & 17.73 & 28.17 & 5.83 & 12.92 \\
\hline
\end{tabular}


Table 5 (concluded)

\begin{tabular}{|c|c|c|c|c|c|c|}
\hline Destination: & & Origin: & Agriculture & Manufacturing & Services & Total \\
\hline \multirow{9}{*}{ Services } & \multirow{3}{*}{ BRA } & 1995 & 10.23 & 11.94 & 19.05 & 15.63 \\
\hline & & 2000 & 10.15 & 11.76 & 17.65 & 14.72 \\
\hline & & 2005 & 10.14 & 11.19 & 17.64 & 13.97 \\
\hline & \multirow{3}{*}{ USA } & 1995 & 17.77 & 17.32 & 26.27 & 23.32 \\
\hline & & 2000 & 18.33 & 21.16 & 29.04 & 26.76 \\
\hline & & 2005 & 16.19 & 21.39 & 28.90 & 26.47 \\
\hline & \multirow{3}{*}{ GBR } & 1995 & 18.55 & 16.01 & 30.72 & 25.56 \\
\hline & & 2000 & 25.08 & 19.59 & 35.01 & 30.60 \\
\hline & & 2005 & 23.88 & 16.83 & 30.57 & 26.22 \\
\hline \multirow{9}{*}{$\begin{array}{l}\text { Total intermediate } \\
\text { consumption }\end{array}$} & \multirow{3}{*}{ BRA } & 1995 & 39.07 & 59.01 & 31.24 & 42.61 \\
\hline & & 2000 & 42.03 & 57.49 & 32.90 & 43.56 \\
\hline & & 2005 & 42.03 & 54.44 & 31.88 & 43.56 \\
\hline & \multirow{3}{*}{ USA } & 1995 & 58.21 & 54.21 & 37.25 & 42.93 \\
\hline & & 2000 & 56.11 & 52.72 & 37.45 & 41.84 \\
\hline & & 2005 & 52.31 & 50.32 & 36.98 & 41.20 \\
\hline & \multirow{3}{*}{ GBR } & 1995 & 48.15 & 47.19 & 39.11 & 41.99 \\
\hline & & 2000 & 46.20 & 45.85 & 41.81 & 42.99 \\
\hline & & 2005 & 47.82 & 45.90 & 36.51 & 39.54 \\
\hline \multirow{9}{*}{ Total taxes and imports } & \multirow{3}{*}{ BRA } & 1995 & 3.54 & 7.48 & 5.33 & 6.03 \\
\hline & & 2000 & 5.35 & 10.02 & 5.53 & 7.34 \\
\hline & & 2005 & 5.35 & 9.59 & 5.20 & 7.34 \\
\hline & \multirow{3}{*}{ USA } & 1995 & 2.05 & 6.76 & 1.42 & 3.09 \\
\hline & & 2000 & 5.33 & 9.43 & 1.76 & 3.89 \\
\hline & & 2005 & 5.71 & 10.87 & 2.46 & 5.03 \\
\hline & \multirow{3}{*}{ GBR } & 1995 & 7.61 & 16.07 & 7.61 & 10.44 \\
\hline & & 2000 & 12.24 & 16.95 & 7.51 & 10.20 \\
\hline & & 2005 & 14.78 & 16.95 & 8.21 & 11.00 \\
\hline \multirow{9}{*}{ Gross value added } & \multirow{3}{*}{ BRA } & 1995 & 57.39 & 33.51 & 63.43 & 51.36 \\
\hline & & 2000 & 52.62 & 32.49 & 61.57 & 49.09 \\
\hline & & 2005 & 52.62 & 35.96 & 62.92 & 49.09 \\
\hline & \multirow{3}{*}{ USA } & 1995 & 39.74 & 39.03 & 61.33 & 53.98 \\
\hline & & 2000 & 38.56 & 37.85 & 60.79 & 54.27 \\
\hline & & 2005 & 41.99 & 38.81 & 60.55 & 53.77 \\
\hline & \multirow{3}{*}{ GBR } & 1995 & 44.24 & 36.74 & 53.28 & 47.57 \\
\hline & & 2000 & 41.56 & 37.20 & 50.68 & 46.82 \\
\hline & & 2005 & 37.39 & 37.15 & 55.28 & 49.46 \\
\hline \multirow{9}{*}{ Gross production value } & \multirow{3}{*}{ BRA } & 1995 & 100.00 & 100.00 & 100.00 & 100.00 \\
\hline & & 2000 & 100.00 & 100.00 & 100.00 & 100.00 \\
\hline & & 2005 & 100.00 & 100.00 & 100.00 & 100.00 \\
\hline & \multirow{3}{*}{ USA } & 1995 & 100.00 & 100.00 & 100.00 & 100.00 \\
\hline & & 2000 & 100.00 & 100.00 & 100.00 & 100.00 \\
\hline & & 2005 & 100.00 & 100.00 & 100.00 & 100.00 \\
\hline & \multirow{3}{*}{ GBR } & 1995 & 100.00 & 100.00 & 100.00 & 100.00 \\
\hline & & 2000 & 100.00 & 100.00 & 100.00 & 100.00 \\
\hline & & 2005 & 100.00 & 100.00 & 100.00 & 100.00 \\
\hline
\end{tabular}

Source: prepared by the authors on the basis of Organization for Economic Cooperation and Development (OECD), "Statistics" [online] http:// stats.oecd.org/Index.aspx?DataSetCode=CSP2010 [viewed in April 2010]. 


\section{IV}

\section{Analysis of the results}

The field of influence is used to quantify the importance of each of the inter-sectoral links, providing a view of the degree of synergy and integration between economic activities, in terms of the purchase and sale of productive inputs.

That analysis is justified because the interaction between manufacturing and services can be explained by two trends: (i) growth in services that are complementary to manufacturing activities; or (ii) the outsourcing of activities (Wölfl, 2005). This integration is probably the main difference between developed and developing economies in terms of the behavior of the services sector (Greenhalgh and Gregory, 2001; Braibant, 2002: Siddiqui and Saleem, 2010). Although it is impossible to separate the two trends, the results of the field-of-influence analysis revealed the most important production links between the two major sectors.

Figures 1 to 9 show the fields of influence in the three countries analysed for 1995, 2000 and 2005. The results for each production link were distinguished by shading ranging from black through scales of grey to indicate above-average fields of influence - in other words - the links of greatest importance for the economy as a whole. Following the input-output structure, the rows represent sectors supplying production inputs, while the columns represent the destination of those inputs.

A horizontal row and a vertical row separate the service sectors (from 17 to 26) from the other sectors and divide the figure into four quadrants, displaying the importance of the intra-and inter-sectoral relations in terms of: (i) the purchase and sale of inputs between goods-producing sectors (purchasers and sellers both from 1 to 16); (ii) the use of service inputs by goods-producing sectors (purchasers from 1 to 16 and sellers from 17 to 26); (iii) the use of goods as inputs in the tertiary sector (purchasers from 17 to 26); and (iv) the purchase and sale of inputs between service-producing sectors.

Figure 1 shows the field of influence by activity sector for Brazil in 1995. In that year, the main links were concentrated in the goods-producing sectors (from 1 to 16), particularly the "textiles, textile products and leather and footwear" sector (5) and the "basic metals and metal products" sector (12). The links between manufacturing and services were not very significant, except for the "finance and insurance" sector (20) which reports several above-average indicators among tertiary activities. Relations between services sectors did not report any link with an above-average field of influence; in other words until 1995 the strongest links in the production chain in Brazil were centred on relations between different manufacturing sectors or between manufacturing and services. This shows the lack of importance of intra-sectoral relations between services for the economy at large; and, compounded with the lack of integration with manufacturing, it shows that the tertiary sector has weak linkages with the rest of the economy.

The structure of the field of influence in 2000 (see figure 2) is little changed from 1995, such that: (i) the important links were concentrated in relations between goods-producing sectors, in particular "agriculture, hunting, forestry and fishing" (1); "textiles, textile products, leather and footwear" (5); "pulp, paper, paper products, printing and publishing" (7); "chemical products" (9); "basic metals and metal products" (12); and "electricity, gas, steam, water and hot water" (15); (ii) relations between services sectors were not significant; and (iii) there was little interaction between goods- and services-producing sectors, either in the purchase or in the sale of inputs.

The importance of each link had changed little in 2005 (see figure 3). Relations between goodsproducing activities became more homogeneous; and the "transport, storage, and communication services" sector (19) was most integrated with the other sectors, mainly goods-producers.

Other tertiary activities became more important as purchasing sectors (columns) and selling sectors (rows), including "commerce; repairs" (17), "finance and insurance" (20) and "business services" (22). During the period analysed, only in 2005 were there any intra-sectoral links in the tertiary sector that were important for the rest of the economy; all of these related to "transport, storage and communication services" (19).

Unlike the situation in Brazil, the most important links in the United Kingdom economy are distributed between goods-producing and service sectors (see figure 4). The 1995 results highlight the importance of the following activities: "electricity, gas, steam, water and hot water" (15), "construction" (16), "business services" (22), "health and social work" (25) and "other collective, social and personal services" (26). 
FIGURE 1

Brazil: Field of influence by activity sector, 1995

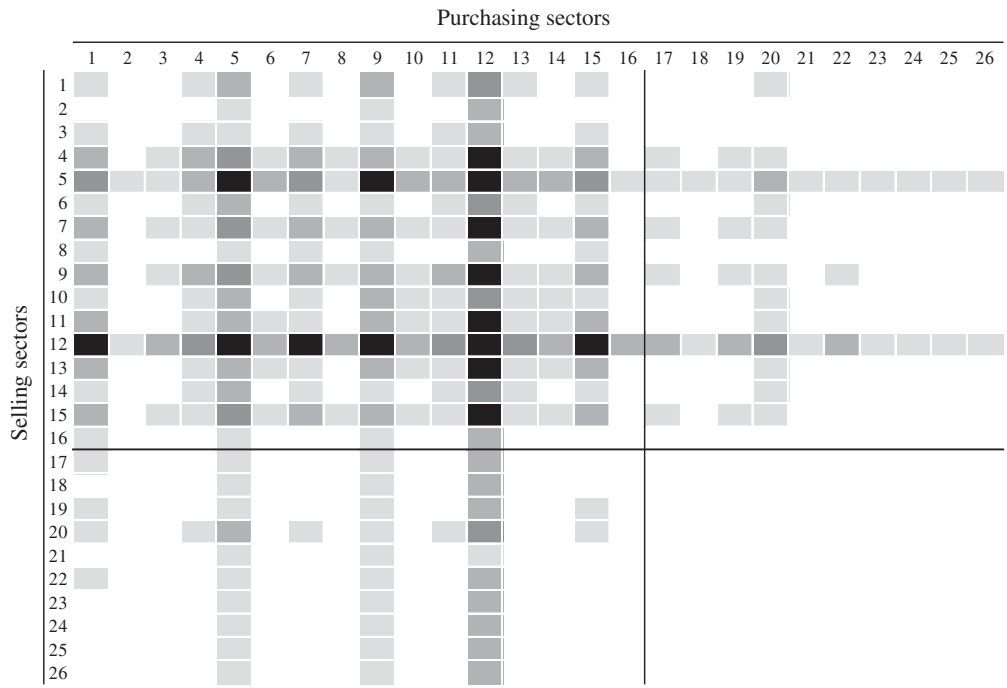

Key

More than three standard deviations above the mean

Between two and three standard deviations above the mean

Between one and two standard deviations above the mean

Between the mean and one standard deviation above the mean

Source: prepared by the authors.

Note: Sector numbers identified in annex 1.

FIGURE 2

Brazil: Field of influence by activity sector, 2000

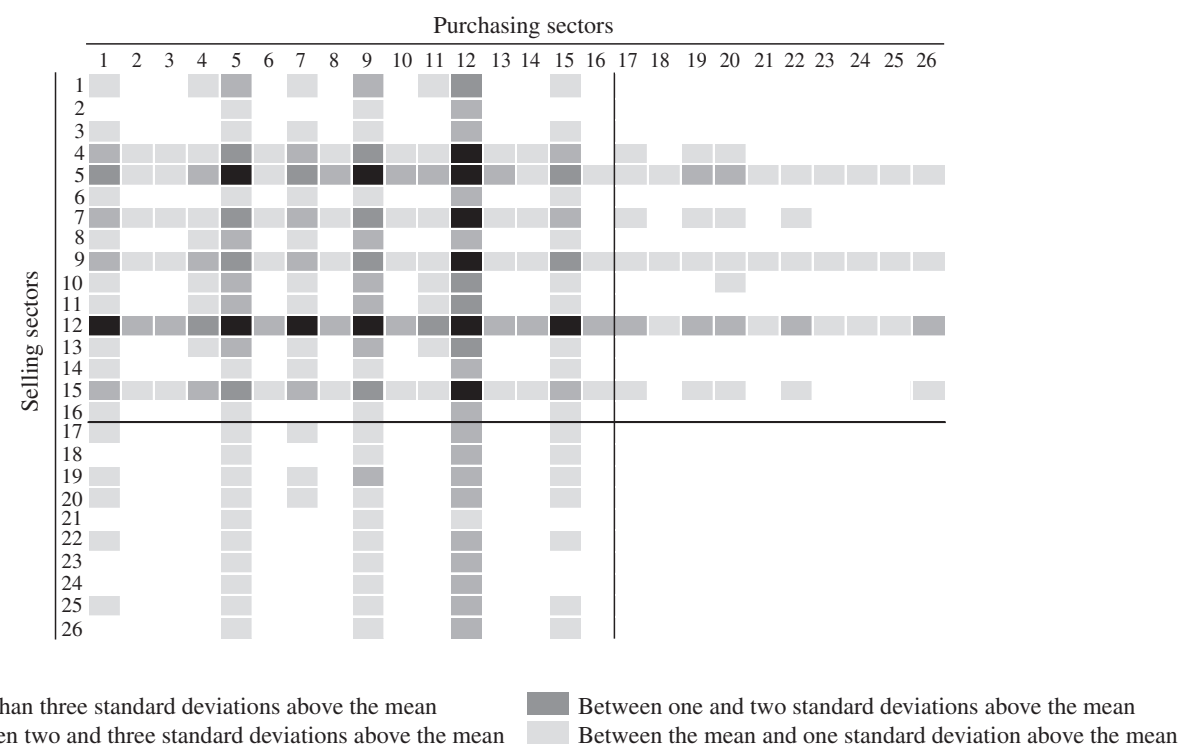

Source: prepared by the authors.

Note: Sector numbers identified in annex 1. 
FIGURE 3

\section{Brazil: Field of influence by activity sector, 2005}

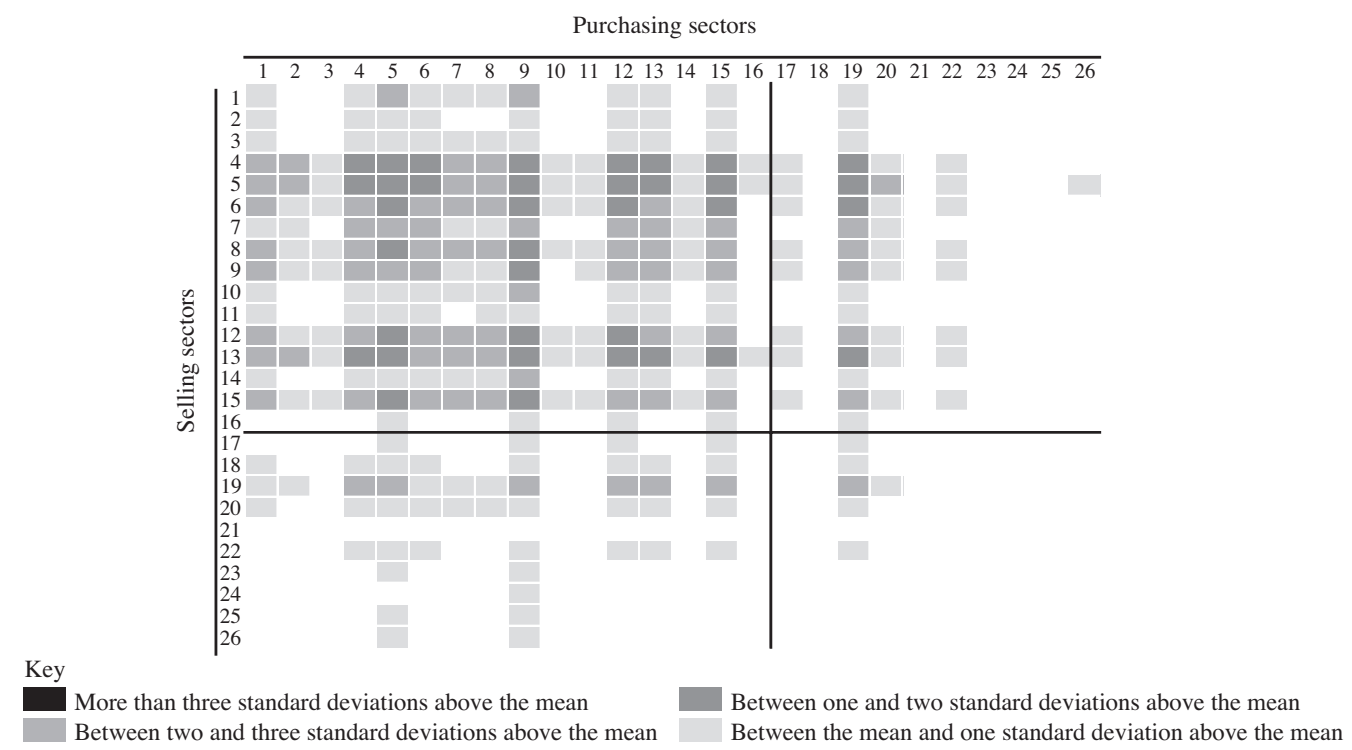

Source: prepared by the authors.

Note: Sector numbers identified in annex 1.

FIGURE 4

United Kingdom: field of influence by activity sector, 1995

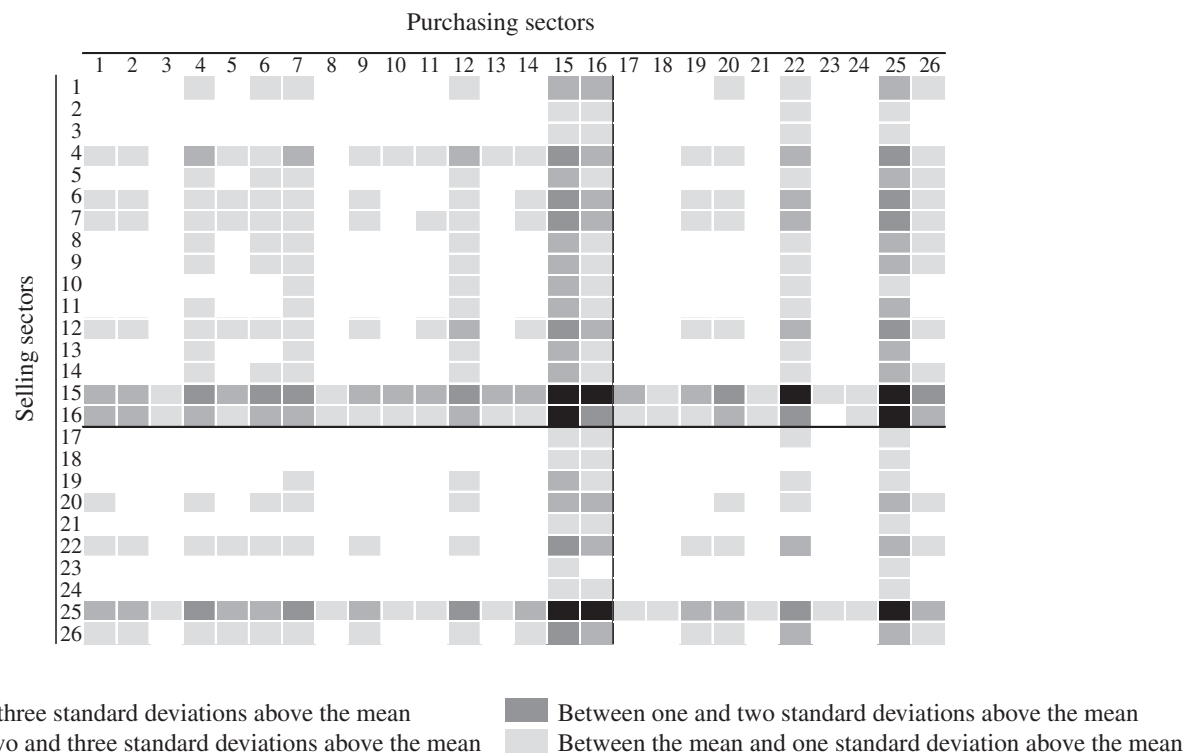

Source: prepared by the authors.

Note: Sector numbers identified in annex 1. 
In these sectors, both the purchasing and selling links were more than averagely important for the economy as a whole, in particular intra-sectoral links which displayed fields of influence of more than three standard deviations above the mean.

In 2000 (see figure 5) the links of the "health and social work" sector (25) weakened, while those of "business services" (22) and "other collective, social and personal services" (26) gained importance as both input suppliers (rows) and input purchasers (columns).

The number of links highlighted between goodsproducing sectors also decreased, particularly in the case of "food products, beverages and tobacco" (4), "wood and wood products and cork" (6), "pulp, paper, paper products, printing and publishing" (7) and "basic metals and metal products" (12). Intra-sectoral links remain the most important, with a field of influence of more than three standard deviations above the mean. In 2005 (see figure 6), the situation was similar to that recorded in 2000: intra-sectoral links distributed throughout the economy and few outstanding activities (both goodsproducers and services).
As in the case of Brazil, the results for the United States in 1995 (see figure 7) show few important links between the service sectors, while the main relations are concentrated in goods-producing sectors, particularly "agriculture, hunting, forestry and fishing" (1), "textiles, textile products, leather and footwear" (5) and "basic metals and metal products" (12).

In the case of relations between the tertiary and other sectors, the activities of "finance and insurance" (20) were the most important, in terms of both the purchase and the sale of inputs from other sectors, followed by "transport, storage and communication services" (19) and "business services" (22).

In 2000 (see figure 8), the purchasing and selling links of the tertiary sector were very important for the United States economy. In that year, the "finance and insurance" sector (20) reported the largest field of influence of the entire economy, with purchasing and selling relations above the mean of all other sectors. In terms of productive-input purchases, there were also significant links in the tertiary sectors of "business services" (22) and transport, storage and communication services" (19).

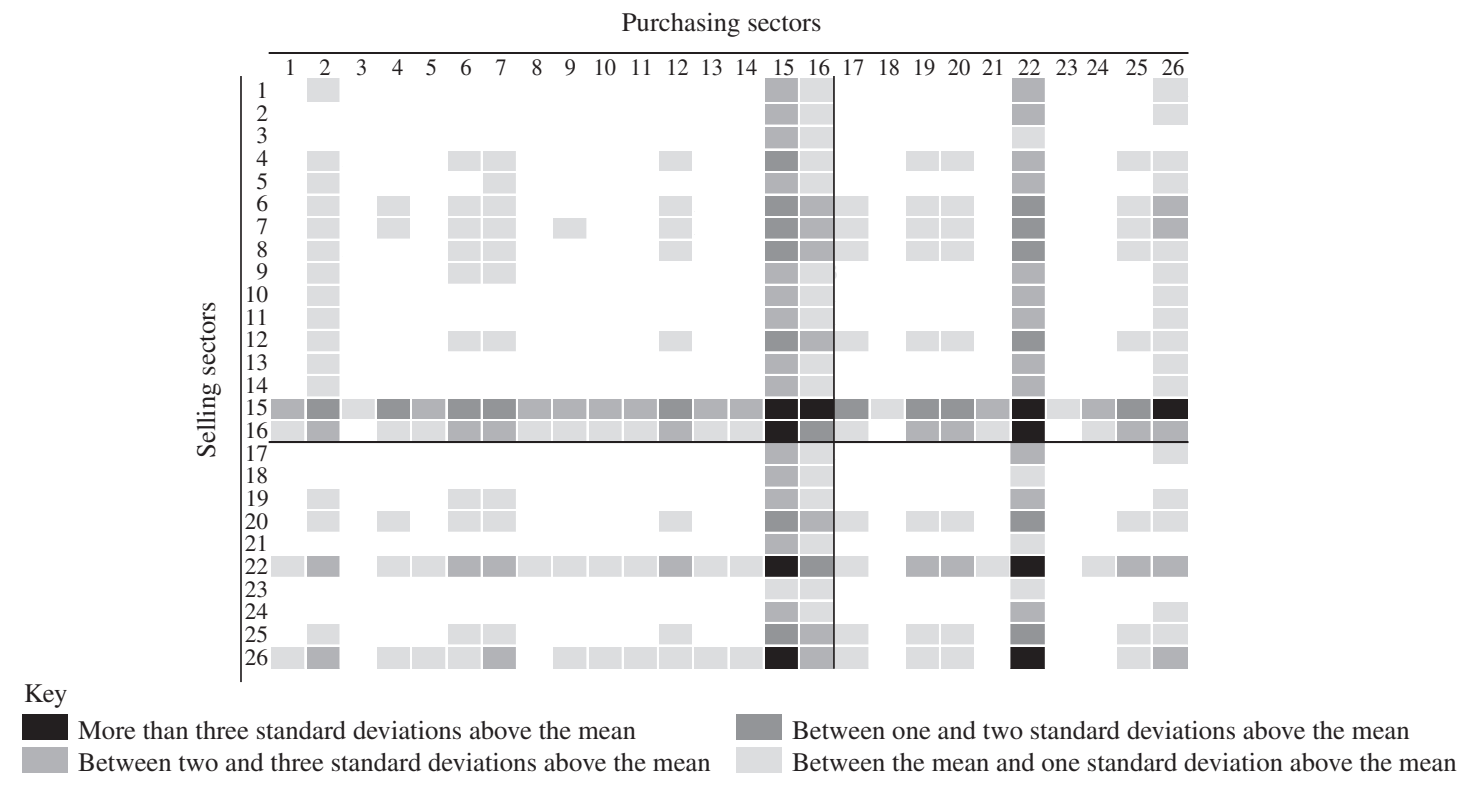

Source: prepared by the authors.

Note: Sector numbers identified in annex 1. 
FIGURE 6

\section{United Kingdom: field of influence by activity sector, 2005}

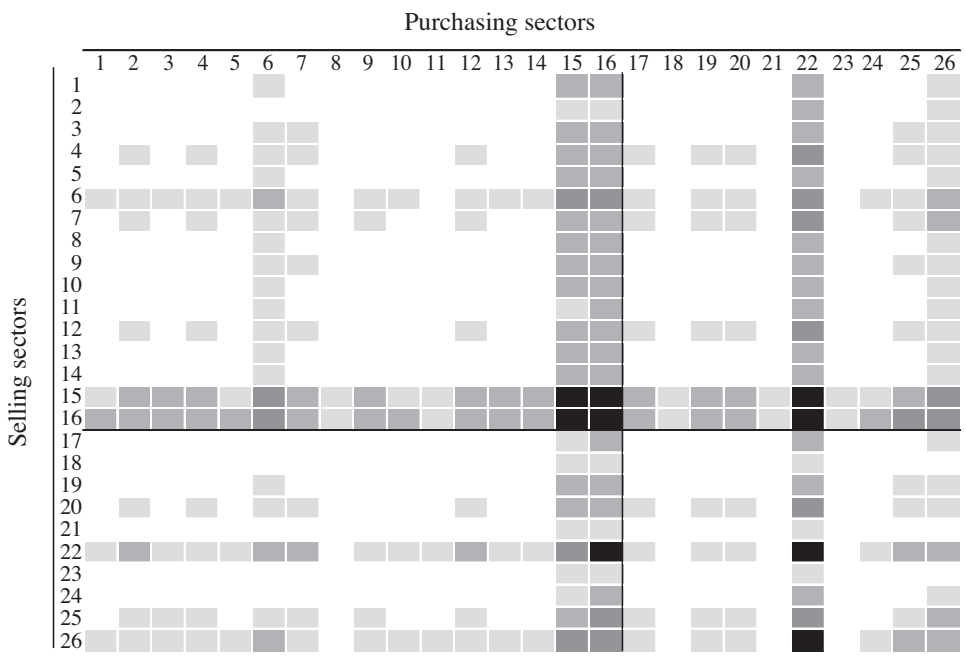

Key

More than three standard deviations above the mean

Between two and three standard deviations above the mean

Between one and two standard deviations above the mean

Between the mean and one standard deviation above the mean

Source: prepared by the authors.

Note: Sector numbers identified in annex 1.

FIGURE 7

United States: Field of influence by activity sector, 1995

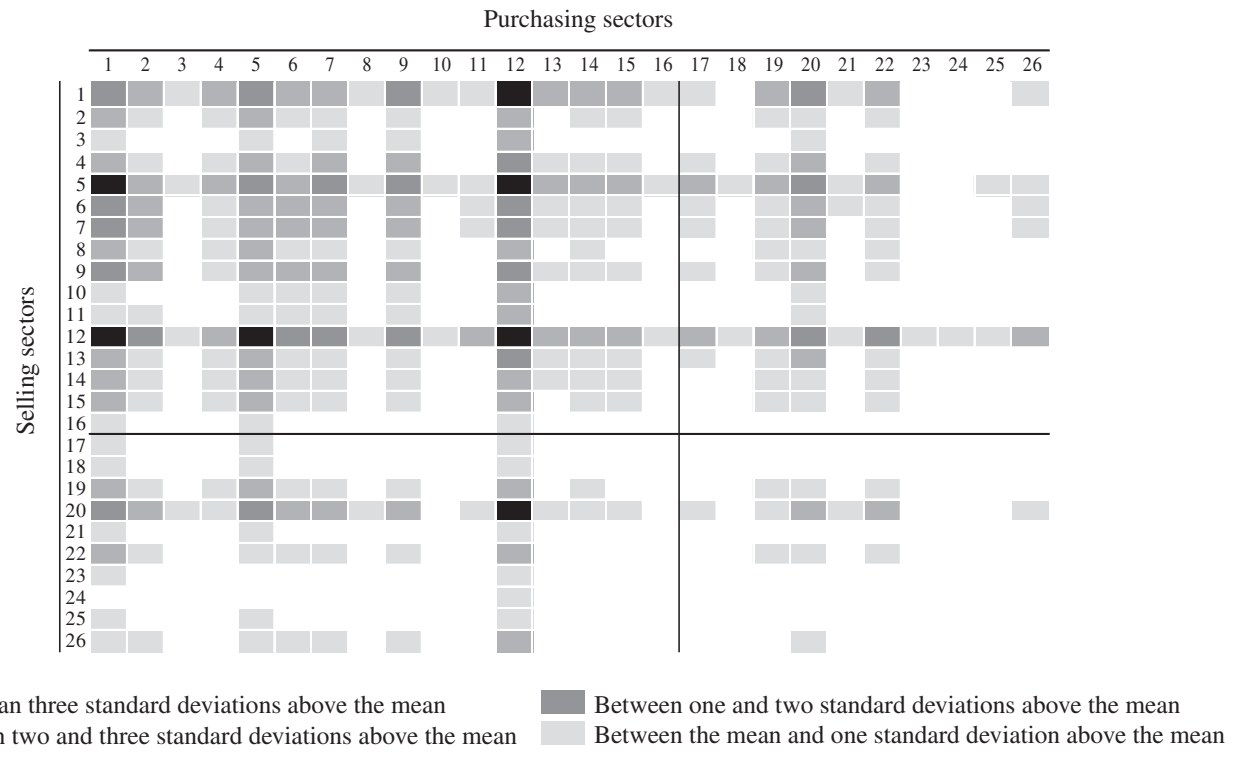

Source: prepared by the authors.

Note: Sector numbers identified in annex 1. 


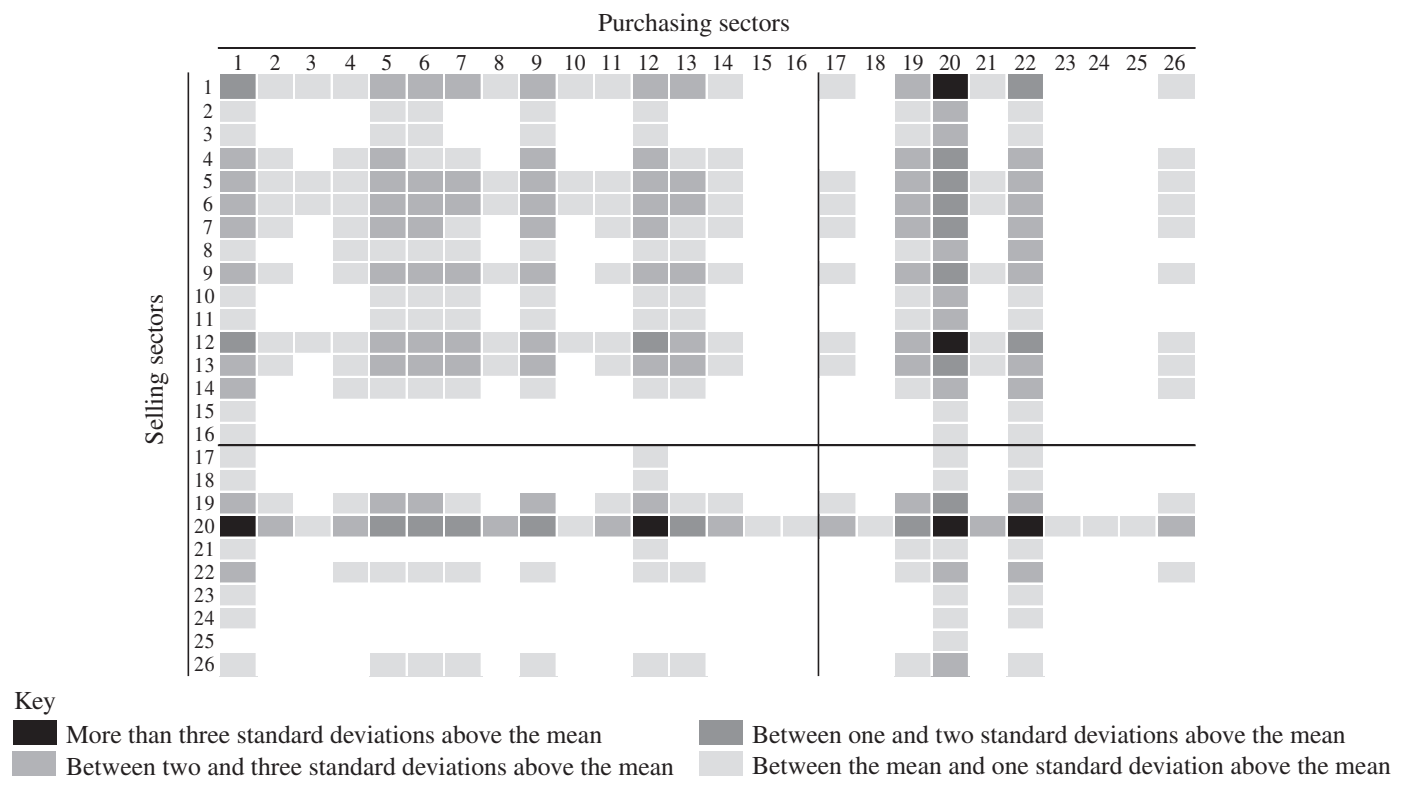

Source: prepared by the authors.

Note: Sector numbers identified in annex 1.

It is worth noting that, even with the intensification of input purchase and sale relations in the services sector, the manufacturing sector maintains its importance mainly in the activities of "agriculture, hunting, forestry and fishing" (1) and "basic metals and metal products" (12).

Lastly, the results of the field-of-influence analysis in the United States for 2005 are similar to those of 2000 (see figure 9). In both years, the most important links were distributed throughout the different sectors, with both goods-producing and service sectors displaying important linkages, including "agriculture, hunting, forestry and fishing" (1), "chemical products" (9), " basic metals and metal products" (12), "transport, storage and communications services (19)", "finance and insurance" (20) and "business services" (22).

In short, field-of-influence analysis reveals significant differences between the production structures of Brazil and the benchmark economies of the United States and the United Kingdom. While in the latter two countries the most important links are distributed throughout the economy and intensify each year in the services sector, in Brazil the main relations remain concentrated in the goods-producing sectors, although the first signs of a trend towards greater integration of the tertiary sector with the rest of the economy could be discerned in 2005 .

According to Greenhalgh and Gregory (2001), Braibant (2002) and Siddiqui and Saleem (2010), these results support the idea that interactions between manufacturing sectors can partly explain the differences in the behaviour of the services sector between developed and developing economies.

Moreover, as Camacho and Rodríguez (2008) point out, services account for an increasing share of intermediate consumption in developed countries, whereas integration between sectors in developing countries remains fragile. 
Key

More than three standard deviations above the mean Between two and three standard deviations above the mean
Purchasing sectors

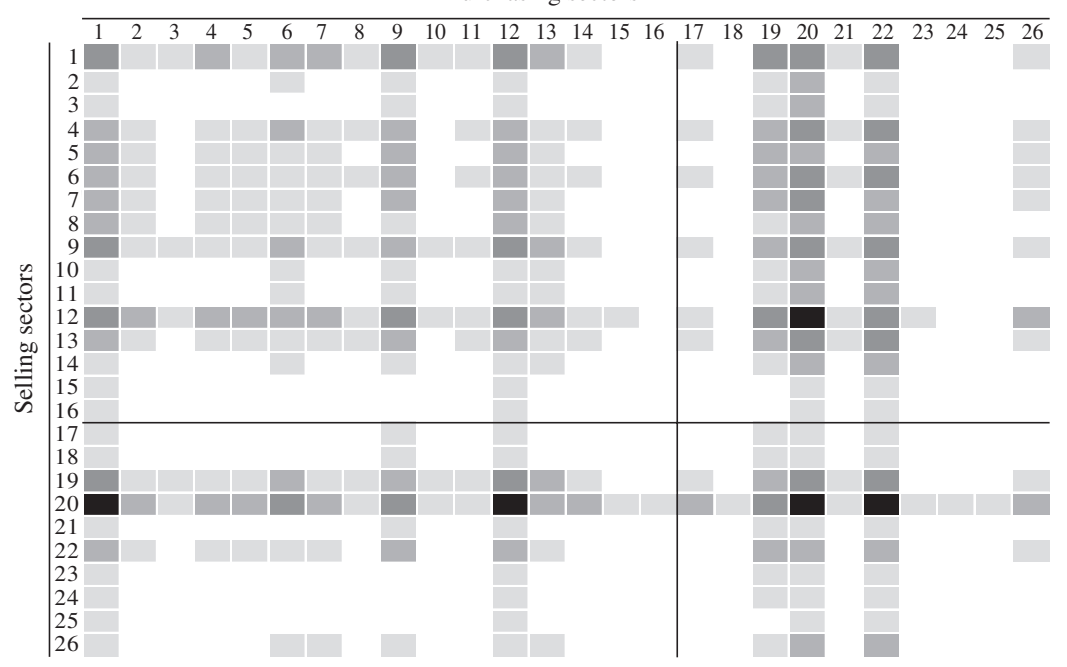

Between one and two standard deviations above the mean Between the mean and one standard deviation above the mean

Source: prepared by the authors.

Note: Sector numbers identified in annex 1.

\section{$\mathrm{V}$}

\section{Conclusions}

This article has aimed to evaluate the tertiarization movement in countries of different development levels, from the viewpoint of intra-and inter-sectoral linkages. Although aggregate tertiary-sector shares are similar in developed and developing countries, there are a number of factors that distinguish them, which makes it crucial to understand how tertiarization is related to economic development. Historical differences mark the expansion of the tertiary sector and result in different production structures, depending on each economy's development level. On this basis, it was decided to analyse the production relations of the tertiary sector in Brazil, the United Kingdom and the United States.

The results of the field-of-influence study show that the services sector in Brazil is still poorly integrated with the rest of the economy, unlike in the other two countries, where the production chain's major links are distributed across all sectors. This may be interpreted as reflecting the degree of maturity of the production structure because, as noted by Siddiqui and Saleem (2010), the division of labour between firms means that synergy between goods production and services improves the economy's competitiveness and leads to consolidated employment and income growth.

In Brazil, agriculture, basic industry (metallurgy and iron and steel, among others) and the food industry account for a larger proportion of the production structure and have a small capacity to generate value-added compared to the same activities in the United States and the United Kingdom. Moreover, the service sectors in the two latter countries have a larger share and greater capacity to add value to each monetary unit used in production (see annex 2).

Production differences can also be explained by the structure of consumption in each country, the characteristics of which differ according to income 
levels. Although $64.71 \%$ of consumption by Brazilian households involves the purchase of services, the fraction of consumption targeted on sectors such as agriculture and the food industry is still high $(3.38 \%$ and $11.51 \%$, respectively) compared to $5.38 \%$ and $7.60 \%$ in the United States and the United Kingdom respectively, according to 2005 data.

This may be interpreted in terms of Engel's law, which postulates that as income rises the proportion spent on food falls (Maroto-Sánchez, 2010). According to Fuchs (1968), the increase in final demand invokes the relation between the composition of expenditures and income levels, because, when incomes rise, the demand for products tends to grow less quickly than the demand for services, thereby increasing the importance of services in the economy. In this case, the demand for entertainment, health, education and transport services, among others, grows (Wölfl, 2005).

The comparative analysis thus shows that to improve the performance of services in Brazil means strengthening both the tertiary sector and manufacturing. As noted by Siddiqui and Saleem (2010), while manufacturing-led growth can produce high growth rates in terms of valueadded in the economy at large, together with significant indirect technological effects owing to higher capitalintensity, it does not create enough jobs or improve social indicators. In contrast, services-led growth raises employment levels and improves socioeconomic indicators (through health services, education, social assistance, research and development). Nonetheless, when growth is fuelled by services, but the manufacturing sector is uncompetitive, the economy will be fragile and volatile. Consequently, the competitiveness and diversification of the economy depend on synergy effects between the two sectors. In the Brazilian case, some activities, including "business services" and "transport, storage and communication services" deserve special attention because they are an essential part of the specialization requirements of the flexible production system. Given their high productivity compared to other sectors, those activities represent growth opportunities for the country. On the other hand, the lower- productivity branches (such as "commerce" and "household services") are essential for job creation.

Productivity is also related to firm size through various factors, such as economies of scale, logistics and the use of advanced technologies in production processes. In 2001, while 97.6\% of firms in Brazil's tertiary sector were microenterprises and small businesses, they accounted for about $60.8 \%$ of jobs, but only $22.3 \%$ of value-added (IBGE, 2003). ${ }^{5}$

Lastly, it is worth noting that these results are compatible with the ideas put forward by Freire (2006b): it is not a matter of confirming the existence of a postindustrial society but of assuming the development of a new type of industrial society in which relations between the tertiary and secondary sectors are even stronger. This requires strengthening production links with the rest of the economy and, as suggested by Domingues and others (2006), integrating technology and regional development policies, creating articulations in specific manufacturing segments, namely in high-technology sectors and those that need specialized services.

The findings reported in this article offer issues for debate on the role that agents can play in the development of the tertiary sector. The Brazilian government could participate in the production integration process either through specific sectoral policies or through an initiative to promote income growth, which would also allow for the consumption of more complex services. In the long term, the consumption of such services would foster greater integration with the industrial sector and convergence towards the structure displayed by developed economies such as the United States and the United Kingdom.

\footnotetext{
5 The Brazilian Geography and Statistical Institute (IBGE) defines "microenterprises" as firms with gross annual revenue of up to R\$ 240,000 , and "small firms" as those with annual gross income of between $\mathrm{R} \$ 240,000$ and $\mathrm{R} \$ 1.2$ million.
} 
ANNEX 1

Aggregation of data provided by the Organization for Economic Cooperation and Development (OECD)

\begin{tabular}{|c|c|c|}
\hline & 26 sectors & OECD Division \\
\hline 1 & Agriculture, hunting, forestry and fishing & 1 \\
\hline 2 & Extractive industry (energy) & 2 \\
\hline 3 & Extractive industry (non-energy) & 3 \\
\hline 4 & Food, beverages and tobacco & 4 \\
\hline 5 & Textiles, textile products, leather and footwear & 5 \\
\hline 6 & Wood and products of wood and cork & 6 \\
\hline 7 & Pulp, paper, paper products, printing and publishing & 7 \\
\hline 8 & Coke, refined petroleum products and nuclear fuel & 8 \\
\hline 9 & Chemical products & $9+10$ \\
\hline 10 & Rubber and plastic products & 11 \\
\hline 11 & Other nonmetallic mineral products & 12 \\
\hline 12 & Basic metals and metal products & $13+14+15$ \\
\hline 13 & Transport equipment & $21+22+23+24$ \\
\hline 14 & Other industries & $16+17+18+19+20+25$ \\
\hline 15 & Electricity, gas, steam, water and hot water supply & $26+27+28+29$ \\
\hline 16 & Construction & 30 \\
\hline 17 & Commerce; repairs & 31 \\
\hline 18 & Hotels and restaurants & 32 \\
\hline 19 & Transport, storage and communication services & $33+34+35+37$ \\
\hline 20 & Finance and insurance & 38 \\
\hline 21 & Real estate activities & 39 \\
\hline 22 & Business services & $40+41+42+43$ \\
\hline 23 & Public administration and defence; compulsory social security & 44 \\
\hline 24 & Education & 45 \\
\hline 25 & Health and social work & 46 \\
\hline 26 & Other community, social and personal services & $36+47+48$ \\
\hline
\end{tabular}

Source: prepared by the authors. 
ANNEX 2

Brazil, United States, United Kingdom: share in gross value added and value added by sector, 1995, 2000 and 2005

(Percentages)

\begin{tabular}{|c|c|c|c|c|c|c|c|c|c|}
\hline \multirow[b]{2}{*}{ Year } & \multicolumn{3}{|c|}{ Brazil } & \multicolumn{3}{|c|}{ United States } & \multicolumn{3}{|c|}{ United Kingdom } \\
\hline & 1995 & 2000 & 2005 & 1995 & 2000 & 2005 & 1995 & 2000 & 2005 \\
\hline Sectors & \multicolumn{9}{|c|}{ Gross production value } \\
\hline Agriculture & 7.48 & 7.09 & 5.14 & 1.98 & 1.40 & 1.37 & 1.91 & 1.15 & 0.89 \\
\hline Extractive industry & 0.91 & 1.85 & 2.82 & 1.20 & 1.19 & 1.72 & 1.92 & 1.93 & 1.75 \\
\hline Food products & 8.35 & 7.75 & 7.05 & 3.55 & 3.06 & 2.87 & 4.57 & 3.36 & 2.91 \\
\hline Durable consumer goods & 3.23 & 3.08 & 2.77 & 2.40 & 1.35 & 0.95 & 1.81 & 1.19 & 0.80 \\
\hline Basic industry & 15.13 & 17.28 & 15.77 & 11.56 & 10.26 & 10.25 & 12.20 & 9.69 & 8.47 \\
\hline Capital goods & 8.83 & 7.79 & 9.13 & 9.63 & 9.45 & 7.31 & 9.85 & 8.94 & 6.70 \\
\hline Non-durable consumer goods & 10.58 & 10.86 & 7.93 & 9.39 & 6.49 & 6.94 & 9.53 & 9.27 & 10.62 \\
\hline Commerce and repair services & 7.87 & 7.77 & 8.45 & 11.76 & 10.33 & 10.10 & 10.32 & 11.44 & 10.86 \\
\hline Services to families & 13.32 & 13.61 & 15.73 & 25.01 & 23.31 & 24.73 & 22.68 & 24.43 & 26.81 \\
\hline Business services & 11.69 & 11.57 & 17.43 & 17.85 & 22.72 & 22.59 & 20.01 & 24.00 & 24.71 \\
\hline \multirow[t]{2}{*}{ Public administration } & 12.61 & 11.37 & 7.79 & 5.67 & 10.44 & 11.18 & 5.20 & 4.60 & 5.47 \\
\hline & \multicolumn{9}{|c|}{ Gross value added } \\
\hline Agriculture & 8.36 & 7.60 & 5.71 & 1.46 & 1.00 & 1.07 & 1.77 & 1.02 & 0.67 \\
\hline Extractive industry & 0.80 & 2.45 & 2.46 & 1.08 & 1.24 & 1.80 & 2.47 & 2.89 & 2.46 \\
\hline Food products & 3.79 & 3.40 & 2.87 & 2.18 & 1.58 & 1.28 & 2.75 & 2.32 & 1.97 \\
\hline Durable consumer goods & 2.00 & 1.81 & 2.10 & 1.61 & 0.84 & 0.63 & 1.46 & 1.04 & 0.63 \\
\hline Basic industry & 9.94 & 10.38 & 8.76 & 8.16 & 7.00 & 6.54 & 9.62 & 7.68 & 6.05 \\
\hline Capital goods & 6.47 & 5.80 & 4.36 & 6.93 & 6.30 & 4.62 & 7.22 & 6.36 & 4.61 \\
\hline Non-durable consumer goods & 10.91 & 11.76 & 8.72 & 8.24 & 6.37 & 6.80 & 7.32 & 7.04 & 7.75 \\
\hline Commerce and repair services & 8.57 & 7.10 & 12.14 & 14.27 & 12.78 & 12.45 & 11.24 & 11.85 & 11.62 \\
\hline Services to families & 18.55 & 20.62 & 22.32 & 31.39 & 27.30 & 28.85 & 28.81 & 30.90 & 32.08 \\
\hline Business services & 14.30 & 12.78 & 20.58 & 18.25 & 23.36 & 23.32 & 21.33 & 23.68 & 26.77 \\
\hline \multirow[t]{2}{*}{ Public administration } & 16.33 & 16.29 & 9.97 & 6.42 & 12.25 & 12.63 & 6.00 & 5.22 & 5.38 \\
\hline & \multicolumn{9}{|c|}{ Ratio between gross value added and gross production value } \\
\hline Agriculture & 57.39 & 52.62 & 54.07 & 39.71 & 38.55 & 41.99 & 44.24 & 41.56 & 37.39 \\
\hline Extractive industry & 45.01 & 65.15 & 42.42 & 48.21 & 56.21 & 56.39 & 61.01 & 69.92 & 69.46 \\
\hline Food products & 23.29 & 21.52 & 19.83 & 33.06 & 27.79 & 24.04 & 28.63 & 32.35 & 33.46 \\
\hline Durable consumer goods & 36.84 & 32.76 & 45.35 & 70.79 & 54.98 & 72.52 & 49.38 & 56.68 & 64.13 \\
\hline Basic industry & 32.77 & 28.87 & 26.17 & 34.41 & 35.06 & 32.77 & 36.32 & 35.90 & 34.06 \\
\hline Capital goods & 37.62 & 36.58 & 23.24 & 38.63 & 35.96 & 33.98 & 34.89 & 33.31 & 34.07 \\
\hline Non-durable consumer goods & 68.27 & 73.50 & 95.77 & 66.08 & 72.57 & 71.59 & 54.21 & 50.55 & 48.10 \\
\hline Commerce and repair services & 55.91 & 44.87 & 69.94 & 65.22 & 66.77 & 66.33 & 51.83 & 48.49 & 52.95 \\
\hline Services to families & 71.52 & 74.39 & 69.04 & 67.43 & 63.20 & 62.72 & 60.45 & 59.22 & 59.18 \\
\hline Business services & 62.86 & 54.25 & 57.44 & 54.91 & 55.50 & 55.51 & 50.73 & 46.19 & 53.57 \\
\hline Public administration & 66.52 & 70.35 & 62.31 & 60.83 & 63.34 & 60.74 & 54.93 & 53.09 & 48.61 \\
\hline
\end{tabular}

Source: prepared by the authors on the basis of Organization for Economic Cooperation and Development (OECD), "Statistics" [online] http:// stats.oecd.org/Index.aspx?DataSetCode=CSP2010 [viewed in April 2010]. 
Amadeo, E.J. and V. Pero (2000), "Adjustment, stabilization and the structure of employment in Brazil", The Journal of Development Studies, vol. 36, No. 4, London, Taylor and Francis.

Arriagada, I. (2007), "Abriendo la caja negra del sector servicios en Chile y Uruguay", Género, familias y trabajo: Rupturas y continuidades. Desafíos para la investigación política, M.A. Gutiérrez, Buenos Aires, Latin American Social Sciences Council.

Bailly, A.S., D. Maillat and W.J. Coffey (1987), "Service activities and regional development: some European examples", Environment and Planning, vol. 19, No. 5, London, Pion Ltd.

Barras, R. (1986), "Towards a theory of innovation in services", Research Policy, vol. 15, No. 4, Amsterdam, Elsevier.

Bell, D. (1973), O advento da sociedade pós-industrial: uma tentativa de previsão social, São Paulo, Cultrix.

Bernardes, R., V. Bessa and A. Kalup (2005), "Serviços na PAEP 2001: reconfigurando a agenda de pesquisas estatísticas de inovação", São Paulo em perspectiva, vol. 19, No. 2, São Paulo, Fundação Seade.

Boden, M. and I. Miles (2000), Services and the Knowledge-Based Economy, London, Continuum.

Bonet, J. (2007), "La terciarización de las estructuras económicas regionales en Colombia", Revista de Economía del Rosario, vol. 10, No. 1, Bogota, Universidad del Rosario.

Braibant, M. (2002), "International comparability of the business services", $13^{\text {th }}$ International Conference on Input-Output Techniques [online] http://www.iioa.org/pdf/13th\%20conf/ Braibant_BusinessServices.pdf.

Camacho, J.A. and M. Rodríguez (2008), "The tertiarisation process in developing economies: an Input-Output Approach", RESER Conference, Stuttgart [online] http://www.reser.net/2008-RESERConference-papers-Stuttgart-25-26-September_a442.html.

Castellacci, F. (2008), "Technological paradigms, regimes and trajectories: manufacturing and service industries in a new taxonomy of sectoral patterns of innovation", Research Policy, vol. 37, No. 6-7, Amsterdam, Elsevier.

Castells, M. (1999), Era da informação - A sociedade em rede, vol. 1, São Paulo, Paz e Terra.

Coffey, W.J. and A.S. Bailly (1991), "Producer services and flexible production: an explanatory analysis", Growth and Change, vol. 22, No. 4, Wiley.

Carneiro, F.G. (1994), "Informalidade e terceirização: duas tendências opostas?", Revista de Economia Política, vol. 14, No. 4, São Paulo.

Delgado, A.P. (2005), "Serviços e desenvolvimento regional", Compêndio de economia regional, J.S. Costa (coord), Coimbra, Principia.

Domingues, E.P. and others (2006), "Organização territorial dos serviços no Brasil: polarização com frágil dispersão", Estrutura e dinâmica do setor de serviços no Brasil, J.A. Negri and L.C. Kubota (orgs.), Brasilia, Institute of Applied Economic Research (IPEA).

Escaith, Hubert (2006), "Industrialización truncada y terciarización sustitutiva en América Latina", Problemas del Desarrollo. Revista Latinoamericana de Economía, vol. 37, No. 147, Mexico City, National Autonomous University of Mexico.

Freire, C.E.T. (2006a), “KIBS no Brasil: um estudo sobre os serviços empresariais intensivos em conhecimento na região metropolitana de São Paulo", São Paulo, University of São Paulo. (2006b), "Um estudo sobre os serviços intensivos em conhecimento no Brasil", Estrutura e dinâmica do setor de serviços no Brasil, J.A. Negri and L.C. Kubota (orgs.), Brasilia, Institute of Applied Economic Research (IPEA).

Fuchs, V.R. (1968), The Service Economy, New York, National Bureau for Economic Research.
Gallouj, F. (2002), "Innovation in services and the attendant old and new myth", Journal of Socio-Economics, vol. 31, No. 2, Amsterdam, Elsevier.

Greenhalgh, C. and M. Gregory (2001), "Structural change and the emergence of the new service economy", Oxford Bulletin of Economics and Statistics, vol. 63, special issue, Oxford, University of Oxford.

Guilhoto, J.J.M. and others (1994), "Índices de ligações e setores-chave na economia brasileira: 1959/80", Pesquisa e planejamento econômico, vol. 24, No. 2, Rio de Janeiro, Institute of Applied Economic Research (IPEA).

Harvey, D. (1992), Condição pós-moderna, São Paulo, Loyola.

Hilgemberg, C.M.T., C.W. Campos and E.M. Hilgemberg (2009), "Produção e emprego no setor de serviços prestados às empresas no Brasil na década de 1990: uma aplicação de insumo-produto", VII Encontro Nacional da Associação Brasileira de Estudos Regionais e Urbanos, São Paulo.

Hoekman, B. and A. Matoo (2008), "Services trade and growth", Policy Research Working Paper Series, No. 4461, Washington, D.C., World Bank.

IBGE (Brazilian Geographical and Statistical Institute), As micro e pequenas empresas comerciais e de serviços no Brasil em 2001, Rio de Janeiro.

Illeris, S. and J. Philippe (1993), "Introduction: the role of services in regional economic growth", The Services Industries Journal, vol. 13, No. 2, Taylor and Francis.

Jesus, J.A. (2005), "A contribuição dos serviços empresariais intensivos em conhecimento (KIBS) para o desenvolvimento regional", Revista desenvolvimento econômico, vol. 7, No. 12, Universidade Salvador (UNIFACS).

Katzman, R. (1984), "Sectoral transformations in employment in Latin America”, CEPAL Review, No. 24, Santiago, Chile.

Kon, A. (2007), "Sobre a economia política do desenvolvimento e a contribuição dos serviços", Revista de Economia Política, vol. 27, No. 1, São Paulo, Centro de Economia Política. (2004), Economia de serviços: teoria e evolução no Brasil, Rio de Janeiro. Campus/Elsevier.

Lima, L.C. and A.M. Rocha (2009), "Reflexões sobre o terciário", GeoTextos, vol. 5, No. 2, December.

López, L.M. and E.P. Cobos (2008), "Desindustrialización, terciarización y estructura metropolitana: un debate conceptual necesario", Cuadernos del CENDES, vol. 25, No. 69, Caracas, Central University of Venezuela.

Maroto-Sánchez, A. (2010), "Growth and productivity in the service sector: the state of the art", Documentos de trabajo, No. 7 , Madrid, Universidad de Alcalá.

Mazumdar, S. (2010), "Industry and services in growth and structural change in India: some unexplored features", Working Paper, No. 20401, Munich, University Library of Munich.

Melo, H.P. and others (1998), "O setor de serviços no Brasil: uma visão global - 1985/95", Texto para discussão, No. 549, Rio de Janeiro, Institute of Applied Economic Research (IPEA).

Miller, R.E. and P.D. Blair (2009), Input-output Analysis: Foundations and Extensions, New York, Cambridge University Press.

Mitra, A. (2010), "Industry-tertiary balance: issues revisited", Journal of Studies on Manufacturing, vol. 1, No. 1, HyperSciences Publisher.

Muller, R. and A. Zenker (2001), "Business services as actors of knowledge transformation: the role of kibs in regional and national innovation systems", Research Policy, vol. 30, No. 9, Amsterdam, Elsevier.

OECD (Organisation for Economic Cooperation and Development) (2010a), "Statistics" [online] http://stats.oecd.org/Index. aspx? DataSetCode=CSP2010. 
(2010b), "Input-Output Tables" [online] http://www.oecd.org/do cument/3/0,3343,en_2649_34445_38071427_1_1_1_1,00.html].

Paiva, P.T.A. (1986), "Cinquenta anos de crescimento populacional e absorção de mão-de obra no Brasil: de 1950 a 2000", Revista brasileira de estudos de população, vol. 3, No. 1, Rio de Janeiro, Associação Brasileira de Estudos Populacionais.

Pandit, K. and E. Casetti (1989), "The shifting patterns of sectoral labor allocation during development: developed versus developing countries", Annals of the Association of American Geographers, vol. 79, No. 3, Washington, D.C., Association of American Geographers.

Phelps, N.A. and T. Ozama (2003), "Contrasts in agglomeration: proto-industrial, industrial and post-industrial forms compared", Progress in Human Geography, vol. 27, No. 5, Sage Publications.

Pilat, D. (2005), "Introduction and synthesis", Enhancing the Performance of the Service Sector, Paris, Organisation for Economic Cooperation and Development (OECD).

Pilat, D. and A. Wölfl (2005), "Measuring the interaction between manufacturing and services", Working Paper, No. 2005/05, Paris, Organisation for Economic Cooperation and Development (OECD).

Pinto, A. (1984), "Metropolization and tertiarization: structural distortions in Latin American development", CEPAL Review, No. 24, Santiago, Chile.

Rocha, F. (1997), "Composição do crescimento dos serviços na economia brasileira: uma análise da matriz insumo-produto - 1985/92", Texto para discussão, No. 522, Rio de Janeiro, Institute of Applied Economic Research (IPEA)

Roggero, A.M. (1976), Urbanización, industrialización y crecimiento del sector servicios en América Latina, Buenos Aires, Ediciones Nueva Visión.
Sassen, S. (1999), "As cidades na economia global", Cadernos de urbanismo, vol. 1, No. 1, Rio de Janeiro, Secretaría Municipal de Urbanismo.

Schettkat, R. and L. Yocarini (2003), "The shift to services employment: a review of the literature", Discussion Paper, No. 964, New York, Institute for the Study of Labor.

Siddiqui, S.H. and H.M.N. Saleem (2010), "Service-led industrial policy for inclusive growth and competitiveness", Competitiveness Review, vol. 20, No. 2, Emerald.

Sonis, M. and G. Hewings (1989), "Error and sensitivity input-output analysis: a new approach", Frontiers of Input-Output Analysis, R.E. Miller, K.R. Polenske and A. Rose (eds.), New York, Oxford.

Storper, M.S. and A.J. Venables (2004), "Buzz: face-a-face contact and the urban economy", Journal of Economic Geography, vol. 4, Oxford University Press.

Vargas, E.R. and P.A. Zawislak (2006), "Inovação em serviços no paradigma da economia do aprendizado: a pertinência de uma dimensão espacial na abordagem dos sistemas de inovação", Revista de administração contemporânea, vol. 10, No. 1, Rio de Janeiro, Associação Nacional de Pos-Graduação e Pesquisa em Administração (ANPAD).

Weller, J. (2004), “Tertiary sector employment in Latin America: between modernity and survival", CEPAL Review, No. 84 (LC/G.2258-P), Santiago, Chile.

Wölfl, A. (2005), "The service economy in OECD countries", Enhancing the Performance of the Service Sector, Paris, Organisation for Economic Cooperation and Development (OECD). 